\title{
Benign Thymus Neoplasm
}

National Cancer Institute

\section{Source}

National Cancer Institute. Benign Thymus Neoplasm. NCI Thesaurus. Code C4458.

A non-metastasizing neoplasm that arises from the thymus. 